\title{
MR Imaging of Uterine Morphology and Dynamic Changes During Lactation(Abstract_要旨)
}

\section{$\operatorname{AUTHOR}(\mathrm{S})$ :}

Daido, Sayaka

\section{CITATION:}

Daido, Sayaka. MR Imaging of Uterine Morphology and Dynamic Changes During Lactation. 京都大学, 2017, 博士(医学)

ISSUE DATE:

2017-01-23

URL:

https://doi.org/10.14989/doctor.r13069

RIGHT:

許諾条件により本文は2017-07-15に公開 


\begin{tabular}{|c|c|c|c|}
\hline & & & \\
\hline 論文題目 & \multicolumn{3}{|c|}{$\begin{array}{l}\text { MR Imaging of Uterine Morphology and Dynamic Changes During } \\
\text { Lactation } \\
\text { (MR 画像における授乳期子宮の形態的変化、機能的変化の観察) }\end{array}$} \\
\hline \multicolumn{4}{|c|}{ 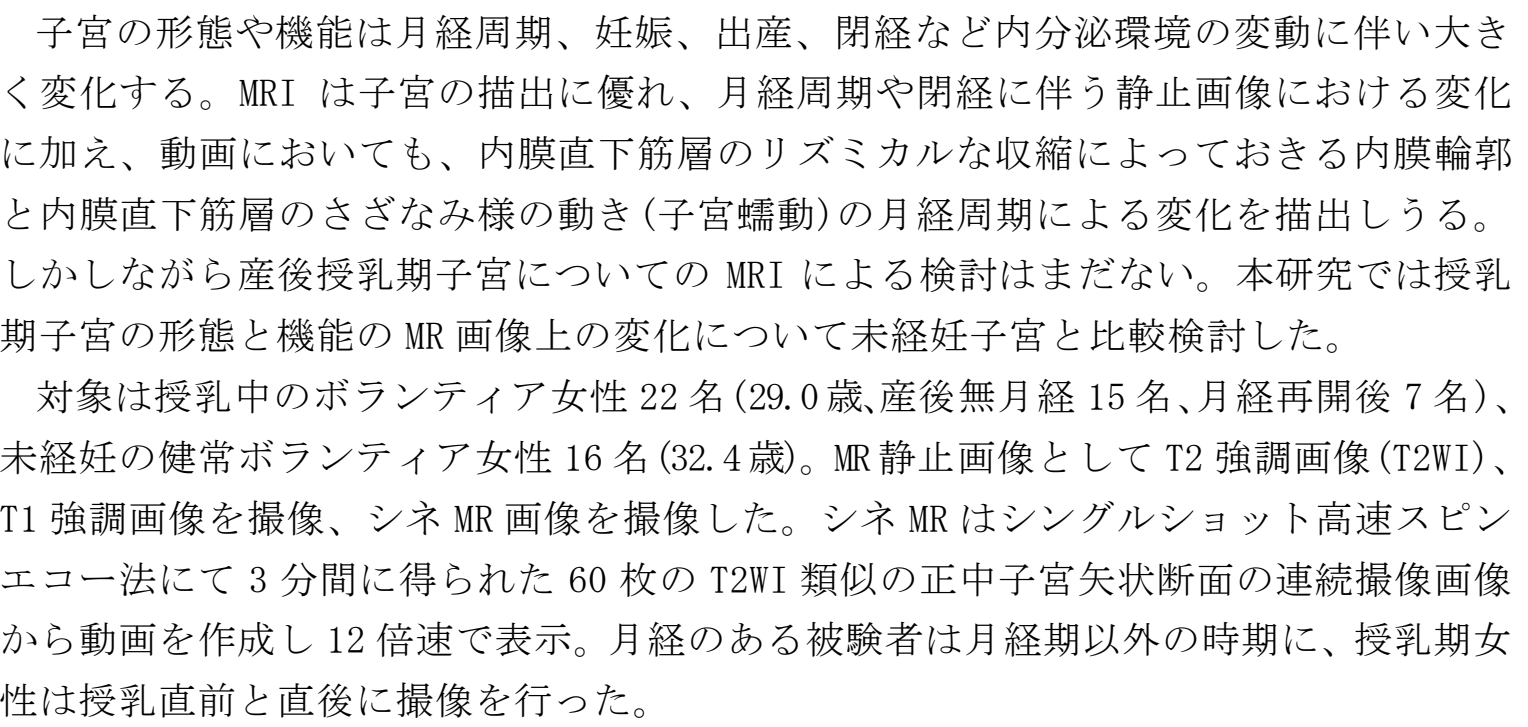 } \\
\hline \multicolumn{4}{|c|}{ 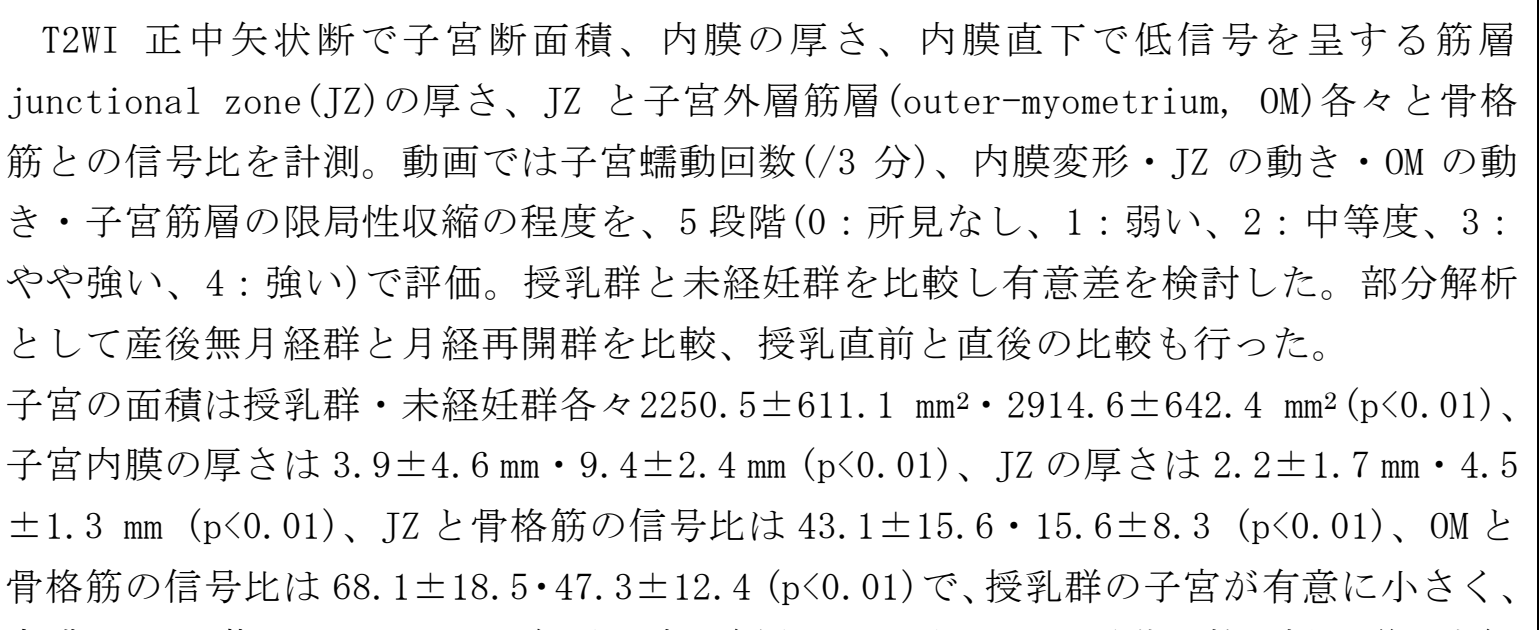 } \\
\hline \multicolumn{4}{|c|}{$\begin{array}{l}\text { 妊群で } 2.8 \pm 1.9 \text { 回・ } 6.3 \pm 1.8 \text { 回 }(\mathrm{p}<0.01) \text { 、内膜変形の程度 } 0.8 \pm 1.0 \cdot 2.5 \pm 1.2 \\
(\mathrm{p}<0.01) \text { 、内膜下筋層の動きの程度 } 2.1 \pm 1.3 \cdot 2.3 \pm 0.6 \quad(\mathrm{p}=1.0) \text { 、外層筋層の動きの }\end{array}$} \\
\hline \multirow{6}{*}{\multicolumn{4}{|c|}{$\begin{array}{l}\text { 程度 } 0.9 \pm 1.1 \cdot 1.4 \pm 1.3(\mathrm{p}=0.082) \text { 、子宮筋層の限局性収縮の程度 } 0.0 \pm 0.2 \cdot 1.0 \pm \\
1.2(\mathrm{p}<0.01) \text { と授乳群で有意に蠕動回数が少なく、内膜変形の程度と子宮収縮が弱か } \\
\text { った。産後無月経群と月経再開群の形態比較では産後無月経群で有意に子宮が小さく、 } \\
\text { 内膜と JZが薄かったが他の項目では有意差がなかった。授乳直前と直後の比較ではい } \\
\text { ずれの項目にも有意差がなかった。産後無月経期には卵巣機能が抑制されていること } \\
\text { が知られており、MRI で認められる子宮形態もその結果の所見として矛盾しない。一 } \\
\text { 方、子宮の収縮に関連する機能については産後無月経群と月経再開群との比較でいず } \\
\text { れの項目でも有意差が認められなかった。 }\end{array}$}} \\
\hline & & & \\
\hline & & & \\
\hline & & & \\
\hline & & & \\
\hline & & & \\
\hline \multicolumn{4}{|r|}{ といて検討した初の研劣である。 } \\
\hline
\end{tabular}

（論文審査の結果の要旨）

本研究では授乳期および未経妊子宮の形態と機能をMRI で評価し比較検討 した。授乳中ボランティア女性 22 名(産後無月経 15 名、月経再開後 7 名)、未 経妊健常ボランティア女性 16 名を対象とし、T2 強調画像矢状断で子宮断面積、 内膜の厚さ、junctional zone (JZ) の厚さ、JZ と子宮外層筋層 (outer-myometrium，0M) 各々と骨格筋との信号比を計測した。動画では子宮蕾 動（JZ の律動的収縮による内膜筋層境界のさざなみ様運動）の回数、内膜変形 の程度、 $\mathrm{JZ} ・ 0 \mathrm{M}$ の動きの程度、筋層の限局性収縮の程度を 5 段階評価した。授 乳群・未経妊群の比較後、部分解析として産後無月経群と月経再開群の比較、 授乳直前と直後の比較も行った。

授乳期子宮は未経妊子宮に比し有意に断面積が小さく、内膜と JZ の厚さが薄 く、JZ と $\mathrm{OM}$ 各々と骨格筋の信号比は高かった。授乳期子宮の方が蠕動回数が 有意に少なく、内膜変形の程度と筋層の限局性収縮が弱かった。産後無月経の 子宮は月経再開後の子宮に比し有意に小さく、内膜と JZ が薄かったが他項目で は有意差は認めなかった。授乳直前と直後の比較では直後で OM の動きの程度 が有意に強かった。

本研究で授乳期子宮は形態、機能ともに未経妊子宮と大きく異なることが示 された。

以上の研究は MRI における正常子宮の形態および機能の生理的多様性の解 明に貢献し生殖医療の発展に寄与寸るところが多い。

したがって、本論文缚士（医学）の学位論文として価值あるものと認める。

なお、本学位授与申請者は、平成 28 年 12 月 6 日実施の論文内容とそれに関連 した試問を受け、合格と認められたものである。 